\title{
The effect of an electricity tax on aggregate electricity consumption: evidence from Basel
}

\author{
Benjamin Krebs ${ }^{1}$ and Simon Luechinger ${ }^{1,2^{*}}$
}

\begin{abstract}
We estimate the effect of an electricity tax on aggregate electricity consumption with the synthetic control method. The tax was introduced in the Swiss city of Basel in 1999 and, together with other tariff changes, increased marginal electricity prices by $5.4-8.0 \%$. We compare the actual and a hypothetical electricity consumption in the years 1999-2006. The latter is a weighted average of electricity consumption in other Swiss cities and captures the hypothetical situation without the tax. We find a statistically insignificant effect of the tax increase of -2.7 to $-1.9 \%$, which implies a rather small, but not unreasonable, price elasticity of between -0.5 and -0.2 . Ambiguous effects on average prices and an unfortunate communication by officials may explain why the innovative reform failed to induce a stronger response.
\end{abstract}

Keywords: Electricity tax, Electricity demand, Synthetic control method

JEL codes: H230, Q410, Q480

\section{Introduction}

We study the effect of an electricity tax on aggregate electricity use in the Swiss city of Basel. Specifically, we look at how electricity use diverges after the introduction of the tax in 1999 from a hypothetical situation without the tax, which we approximate by a weighted average of usage in other Swiss cities. Even though the tax is substantial, our estimates show only a relatively small and statistically insignificant negative effect.

Several countries, states, and cities have introduced electricity taxes aimed at cutting usage. For example, in Denmark and Germany, the tax share (even excluding VAT) of household electricity prices are 43 and 38\%, respectively (IEA 2018, p. xxiii). However, there is little evidence on whether such taxes work as intended. Therefore, we assess the effectiveness of the electricity tax in Basel. In 1999, Basel introduced an electricity tax together

${ }^{*}$ Correspondence: simon.luechinger@unilu.ch

'University of Lucerne, Frohburgstrasse 3, 6002 Lucerne, Switzerland

2ETH Zurich, KOF Swiss Economic Institute, Zurich, Switzerland with other changes to the structure of electricity tariffs. As a result, marginal electricity prices substantially increased for households and most businesses by 14-36 and $6-41 \%$, respectively. Only the largest industrial users were exempt. The official goal of the tax is to encourage electricity conservation. ${ }^{1}$

We estimate the effect of the electricity tax with the synthetic control method (Abadie and Gardeazabal 2003; Abadie et al. 2010; 2015). We compare how electricity consumption evolved in the years 1999-2006 after the introduction of the tax to how it would have evolved without the tax. The hypothetical path of electricity use is a weighted average of usage in other Swiss cities with weights that allow us to closely approximate Basel's electricity consumption and its determinants in the years 1985-1998.

In all years since 1999, observed electricity consumption in Basel is below its predicted value without the tax.

\footnotetext{
${ }^{1}$ See Basel's energy law ("Energiegesetz"), article 27, or the website of Basel's office for the environment and energy, http://www.aue.bs.ch/energie/ stromspar-fonds.html; accessed June 9, 2019.
} 
However, this difference is not statistically significant and relatively small. Therefore, the electricity tax seems to have been at best moderately effective in reducing electricity usage. We offer two related explanations for this finding. First, the adoption of the tax and the simultaneous changes to the tariff structure had clear effects on marginal prices but ambiguous effects on average prices. Thus, our results are in line with previous findings regarding the importance of average prices (Ito 2014). Second, the official communication emphasized the small expected effects on overall electricity costs for consumers. As both explanations are context-specific, we do not argue that electricity taxes are ineffective in general.

Our paper contributes to a small literature evaluating the effectiveness of electricity taxes. Most importantly, there is an earlier study on the effects of Basel's electricity tax by Iten et al. (2003). They compare the developments of electricity consumption in Basel and in the rest of Switzerland in different sectors in the years 1988-2001. Based on these comparisons, they conclude that the tax had no effect (Iten et al. 2003, pp. 78-81, 94-96, and 129130). However, while this approach is interesting, the rest of Switzerland is not a good comparison for Basel. The electricity consumption evolved very differently in Basel compared to the rest of Switzerland in the years before the tax. This is clearly visible in the relevant figures in Iten et al. (2003, pp. 79, 81, 95, 96, and 130) and in Fig. 4 in Appendix A. The synthetic control method allows us to find a more adequate comparison and, in addition, to assess the statistical significance of any effect.

Further, three papers analyze the effects of carbon, energy, or electricity taxes on energy or electricity use in the manufacturing sector in Denmark (Bjørner and Jensen 2002), Germany (Gerster 2015), and the UK (Martin et al. 2014). All three papers exploit tax exemptions or rebates for heavy users or polluters to estimate the effects. The Danish tax was introduced in 1993 and increased electricity prices by $15 \%$. Bjørner and Jensen (2002) find a negative effect on energy use with an implied elasticity of -0.44 . The German tax adopted in 2000 raised electricity prices by 17 and $25 \%$ in 2010 and 2011 . Gerster (2015) estimates a negative effect on electricity consumption and elasticities of -1.58 and -2.32 . Martin et al. (2014) document negative effects on electricity consumption of the tax, which was introduced in 2001 in the UK and raised electricity prices by $10 \%$. They report an elasticity of -1.51 . In contrast to these papers, we are interested in the effect of the electricity tax on electricity consumption overall, not only in the manufacturing sector.

Our paper is also related to previous papers estimating electricity demand with aggregate data at the level of US states (e.g., Maddala et al. 1997; Alberini and Filippini 2011; Aroonruengsawat et al. 2012), Spanish provinces or regions (e.g., Blázquez et al. 2013; Romero-
Jordán et al. 2014), and, especially, Swiss cities (Filippini 1999, 2011; Boogen et al. 2017). For the Swiss cities, estimates of long-term elasticities amount to -0.35 for the years 1987-1990 (Filippini 1999), -2.26 to -1.27 for the years $2000-2006$ (Filippini 2011), and -0.58 for the years 2006-2012 (Boogen et al. 2017) ${ }^{2}$.

\section{Institutional background}

In 1999, Basel's authorities modified electricity prices in three ways: They introduced the electricity tax, compensated the abolishment of a fixed monthly fee with an increase in marginal prices, and replaced recurring temporary rebates by a reduction in marginal prices ${ }^{3}$. The trigger for these changes was the requirement to reduce electricity prices to avert excessive profits of Basel's electric utility, which were capped by law. Before, the utility handed back excessive profits to its customers by retroactively granting temporary rebates of $5 \%$. To provide incentives for electricity conservation rather than for increased electricity usage, Basel's government simultaneously replaced the fixed monthly fee with higher marginal prices and introduced the electricity tax. Together, all three changes substantially increased marginal electricity prices.

The effects on marginal and average electricity prices differed across groups of customers, tariff structures, and consumption levels. There are four customer groups, namely households and small, mid-sized, and large businesses. Households could choose between a single tariff and a double tariff with different prices for day and night hours. The former was more popular. For households with this single tariff, the increase in the marginal price was $14.4 \%$. Because the fixed monthly fee was replaced by higher marginal prices and also by a monthly minimum price, the change in the average price depended on the consumption level: It decreased for monthly consumption levels below 421 kilowatt hours and increased for consumption levels above that amount. In 1998, the average Swiss household used 412 kilowatt hours per month (SFOE 1999, p. 6). Because of the introduction of the minimal price, even the marginal price decreased to zero for consumption levels below around 33 kilowatt hours. However, this amount is well below the consumption level of

\footnotetext{
${ }^{2}$ Long-term elasticities capture the full response of electricity consumers to price changes. More pragmatically, (Labandeira et al. 2017) use the time horizon of one year to differentiate between short-term and long-term elasticities. Since we assess the response in eight tax years, we interpret our estimates as long-term effects.

${ }^{3}$ This section is based on (Iten et al. 2003, pp. 36-47) and the relevant decrees, i.e., the decrees on electricity tariffs ("Verordnung betreffend

Elektrizitätstarife") from November 29, 1994, and May 11, 1999, and the decree on the electricity tax ("Verordnung zur Lenkungsabgabe und zum Strompreis-Bonus") from May 11, 1999 (see notes to Table 2 in Appendix A for details).
} 


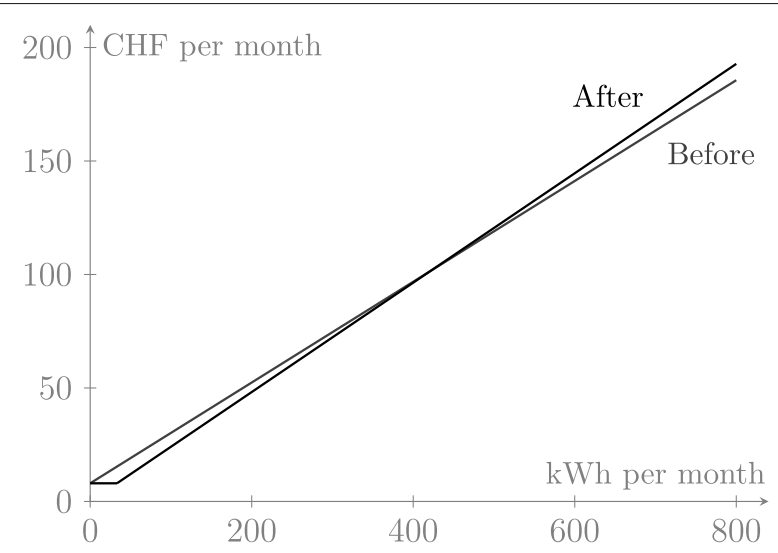

Fig. 1 Cost schedule for the household single tariff before and after the electricity tax. Sources: Decree on electricity tariffs ("Verordnung betreffend Elektrizitätstarife") from November 29, 1994; Decree on electricity tariffs ("Verordnung betreffend Elektrizitätstarife") from May 11, 1999; Decree on the electricity tax ("Verordnung zur Lenkungsabgabe und zum Strompreis-Bonus") from May 11, 1999; Iten et al. (2003, pp. 7-8)

most, if not all, households ${ }^{4}$. All these changes to electricity prices of the single tariff for households are illustrated in Fig. 1.

For households with the double tariff, marginal prices increased by $36.1-36.3 \%$. Using 1998 consumption levels as weights, the weighted average of the increase in marginal prices for households was $19.9 \%$. If we ignore the temporary rebates before 1999 in our calculations, marginal prices increased by $8.9 \%$ for households with the single tariff, by $29.6-29.7 \%$ for households with the double tariff, and by $14.1 \%$ on average. Small businesses also had the choice between two tariffs. For small businesses, the marginal prices rose by $6.5 \%$ in case of the single tariff, by $16.9-42.0 \%$ in case of the double tariff, and by $13.6 \%$ on average. Without the temporary rebates before 1999, the corresponding figures are 1.4\%, 11.3$35.1 \%$, and $8.1 \%$, respectively. For all households and small businesses, changes in average prices depended on consumption levels. For mid-sized businesses marginal prices differed between summer and winter and day and night. They grew by $6.0-41.1 \%$ or $16.5 \%$ on average (or, without the temporary rebates, by $0.9-34.3 \%$ or $10.9 \%)$. The average increase in the marginal price for households and small and mid-sized businesses was $17.1 \%$ (or $11.5 \%$ without the temporary rebates). Table 2 in Appendix A summarizes the price changes for these groups of customers.

We lack information on prices of large businesses. The heaviest users, an international organization, and public transport companies were exempt from the electricity

\footnotetext{
${ }^{4}$ In the year 2000, an average refrigerator used already more than 300 kilowatt hours per year (SFOE 2016, p. 4).
}

tax. Together, their share of electricity consumption in 1998 was $31.9 \%$ (Iten et al. 2003, p. 208). According to a representative of Basel's office for the environment and energy, there were no systematic changes in the electricity prices for these companies. ${ }^{5}$ Other large businesses were not exempt from the electricity tax. Nevertheless, since we have no information on prices for these companies, we conservatively assume that marginal prices remained constant. With this assumption, marginal prices across all consumers rose by $8.0 \%$ on average (or, $5.4 \%$ without the temporary rebates). Note that $8.0 \%$ is a conservative lower bound for the overall marginal price increase.

The revenues of the electricity tax are refunded to households and non-exempt businesses based on the number of household members or the wage bill. Thus, this refund has not affected marginal prices. Further, it counteracts the negative income effect from the electricity tax. Therefore, our estimates essentially capture the substitution effect.

\section{Empirical strategy and data}

To estimate the causal effect of the electricity tax in Basel, we use the synthetic control method (Abadie and Gardeazabal 2003; Abadie et al. 2010, 2015). The causal effect of the tax is the difference between the observed electricity consumption with the tax and the hypothetical one without it. We approximate the hypothetical electricity consumption as a weighted average of the electricity consumption in other Swiss cities. This will be more convincing the closer the weighted average across the other cities resembles annual pre-tax consumption and its determinants (Abadie et al. 2010, 2015; Kaul et al. 2018; Botosaru and Ferman 2019). The distances between the values of these pre-tax variables in Basel and in the weighted average of the other cities depend on city weights. The objective is to minimize a weighted average of these distances squared, whereby weights reflect the importance of the pre-tax variables for the development of electricity usage (Eq. 1 in Abadie et al. 2015). Thus, the objective function contains sets of city and variable weights. We use the synthetic control method algorithm to determine the values of both sets of weights that solve the minimization problem.

An important question is which pre-tax variables should be included in the minimization process. Several recent contributions address this aspect (Ferman et al. 2018; Kaul et al. 2018). Ferman et al. (2018) demonstrate that results are sensitive to changes in specification. Thereby, they focus on variants of including different values and combinations of-in our case-pre-tax electricity consumption. Two popular examples are specifications that include (i) all pre-tax values or (ii) only their mean. Ferman et al. (2018) show that the results are less sensitive

\footnotetext{
${ }^{5}$ Email correspondence from March 7, 2017.
} 
with specifications, such as (i) above, where the number of included pre-tax values increases with the length of the pre-tax period. Therefore, they recommend using such specifications. However, Kaul et al. (2018) point out that specifications with a large number of pre-tax consumption values render other determinants less important or, in the case of specification (i), completely unimportant. As discussed by the authors, ignoring these determinants may lead to biased results, especially if they really hold predictive power and if the pre-tax period is short. Given these findings and our data with 14 pre-tax years, we estimate our main results using three different specifications: Specification (i) includes all pre-tax consumption values and no other determinants. Specification (ii) includes the mean of all pre-tax consumption values together with other determinants. We collected nine determinants of electricity consumption that are theoretically plausible or that have been suggested in the previous literature. Specification (iii) includes no pre-tax consumption values but only other determinants.

The synthetic control method relies on numerical methods to determine the city and variable weights. Therefore, it may find a local optimum rather than the global one and estimates may depend on theoretically irrelevant aspects. In particular, the estimates depend on the order of variables and cities (Klößner et al. 2018). To address this issue, we estimate 1000 different permutations of ordering cities and variables for all three specifications. We discuss the sensitivity of our estimates to these orders and select for the main results those permutations with the smallest root mean squared prediction error between observed and hypothetical electricity consumption in the pre-tax period $^{6}$.

As the preceding discussion suggests, we require data on annual electricity consumption and its determinants in Swiss cities. We were able to collect data on electricity consumption for 35 cities. Importantly, this includes many larger and all top-ten cities, a group which Basel belongs to $^{7}$. Our sample period covers the years 1985-2006. 1985 is the first year with available data for Basel, and 2006 is the last year with complete data for all 35 cities $^{8}$. Thus, our sample period consists of 14 pre-tax and eight tax years. Whenever possible, we use net electricity consumption data excluding grid losses and utilities' own consumption. Further, we divide total consumption by the number of

\footnotetext{
${ }^{6}$ Another selection criterion would be the pre-tax differences in electricity usage and its determinants in Basel and other cities (see Eq. 1 in Abadie et al. 2015). In Section 4, we briefly discuss the corresponding results. For specification (i) with pre-tax electricity consumption only, we just change the order of the cities, which implies 35! possible permutations. For specifications (ii) and (iii), we change the order of variables and cities, which implies $35 ! \times 10$. and 35 ! $\times 9$ ! possible permutations, respectively. Out of these possible permutations, we randomly select 1000 for each specification.

${ }^{7}$ Officially, there are 141 cities in the year 2000 (SFSO 2008).

${ }^{8}$ Because utility data no longer coincide with administrative areas since the partial electricity market liberalization in 2009, an extension of the sample period of more than two years is impossible anyway.
}

households to account for large differences in city size. Data on the number of households are from the decennial census (see Appendix B) and interpolated in intermediate years.

The electricity usage data predominantly come from electric utilities (see Appendix B for data sources). In the case of Lucerne, the data are from the cantonal statistical office. In some cases, we complement utility data with cantonal data to interpolate missing years (see below). We either received the data from the utilities directly or collected them from their annual reports in the largest archive on the Swiss economy (Schweizer Wirtschaftsarchiv). The consumption data do not always correspond to the territory of the city because it refers to a larger coverage area including surrounding municipalities (see Appendix B for details). If so, we account for these deviations for all variables.

In some cities, data on electricity consumption are missing in individual years. We employ three methods to fill in these missing values. First, we extrapolate consumption data using cantonal data for missing years and the ratio of municipal to cantonal consumption in the four preceding or succeeding years for Chur (2002-2006), Neuchâtel (1985), Schaffhausen (1985-1990), and Zug (2006). Second, we interpolate net electricity consumption using gross electricity consumption and the ratio of these two variables in the two preceding and two succeeding years (Aarau 1992-1999) and we extrapolate net electricity consumption using total sales (including sales to other utilities) and the ratio of these two variables in the four succeeding years (Lausanne 1985-1986). Third, we linearly interpolate individual missing years (La Chaux-de-Fonds 2003, St. Gallen 1994 and 2004, and Zug 1986).

In the following, we discuss our nine determinants of electricity consumption. The values of these determinants refer to one pre-tax year or the mean of several pre-tax years. See Appendix B for the data sources.

Average electricity intensity captures differences in sectoral composition across cities and their implications for electricity usage. To calculate this variable, we start with the average electricity use per full-time equivalent in each sector in Switzerland and the year 2000/2001 ${ }^{9}$. We then compute city-specific weighted averages of this variable using sectoral full-time equivalents in 1995.

Electric heating and electric boiler measure the share of electrically heated living area and the share of individuals living in a flat with an electric boiler, respectively, in 1990. In the year 2000, heating and hot water accounted for $84 \%$ of residential energy use in Switzerland (SFOE 2015). Therefore, the share of electric appliances in these domains is arguably an important determinant of electric-

\footnotetext{
${ }^{9}$ We have data on electricity use per sector in 2000 and the number of full-time equivalents per sector in 2001.
} 
ity use and its development over time. Similar variables have been suggested by Romero-Jordán et al. (2014).

Rooms per apartment in 1990 allows us to consider variations in the typical apartment size. This might be important as households in larger apartments generally consume more electricity.

Average income is the net income per taxpayer declared for the federal income tax in the tax period 1997/1998. Maddala et al. (1997), Alberini and Filippini (2011), Filippini (2011), Aroonruengsawat et al. (2012), Blázquez et al. (2013), Romero-Jordán et al. (2014), and Boogen et al. (2017) use related variables.

Working-age population and average age are the share of the people who are 18-65 years old and the average age, respectively, in the year 1990.

Heating-degree days (HDD) and cooling-degree days $(C D D)$ indicate climatic conditions and are defined as the annual sum of the negative deviations of daily mean temperatures from $12{ }^{\circ} \mathrm{C}$ and as the annual sum of the positive deviations of daily mean temperatures from $18.3^{\circ} \mathrm{C}$, respectively. Both are averaged over the pre-tax period. These are standard variables in studies on electricity demand such as Maddala et al. (1997); Alberini and Filippini (2011); Filippini (2011); Aroonruengsawat et al. (2012); Blázquez et al. (2013); Romero-Jordán et al. (2014); and Boogen et al. (2017).

\section{Results}

Figure 2 shows that Basel's electricity consumption and its change are well in the range of the levels and changes of the other cities. This is an essential requirement for the synthetic control method. The points on the left represent the consumption levels of the cities in our sample in 1985 , the points on the right the consumption levels in 2006, and the steepness of the connecting line the percentage changes between those years. In Basel, consumption in 1985 and 2006 amounted to 13.1 and 15.9 MWh per household, respectively. Around a third of the other cities had higher consumption levels in those years. The increase of $21.4 \%$ is comparatively low; around two thirds of the cities experienced a larger increase.

As discussed in Section 3, we always estimate three different specifications. The specifications include different sets of pre-tax variables for which we try to approximate Basel's values with a weighted average of the values in the other cities. We try to approximate pre-tax levels of electricity consumption in specification (i), average pre-tax electricity consumption and the determinants of electricity consumption in specification (ii), and the determinants only in specification (iii).

In all three specifications, our approximations are successful. Table 1 reports the values of all pre-tax variables for Basel, for an unweighted average across cities, and for three weighted averages corresponding to the specifica- tions (see columns "values"). As intended, specification (i) better approximates pre-tax consumption levels in 13 out of 14 years compared to the unweighted average. Specifications (ii) and (iii) not only outperform the unweighted average in the case of the pre-tax average and eight of nine determinants but also in the case of 13 out of 14 annual pre-tax levels. For completeness, Table 1 also presents the variable weights. Further, Table 3 in Appendix A lists the city weights. Nine cities receive a weight greater than zero in specification (i), six in specification (ii), and four in specification (iii).

Our main results are shown in Fig. 3. It depicts the observed electricity usage in Basel and the estimates of the hypothetical usage without the tax in Panel A, and the difference between observed and hypothetical usage in Panel B. As can be seen, our estimates of the hypothetical electricity consumption are very close to the observed level in the years 1985-1998 before the tax and slightly above the observed level in the years thereafter ${ }^{10}$. This is true for all our specifications. The average estimated reduction of electricity usage in the years 1999-2006 after the tax is $-0.433 \mathrm{MWh}$ per household or $-2.7 \%$ compared to the hypothetical situation in specification (i), $-0.344 \mathrm{MWh}$ per household or $-2.2 \%$ in specification (ii), and -0.300 MWh per household or $-1.9 \%$ in specification (iii).

To assess the statistical significance of these reductions, we follow the approach suggested by Abadie et al. (2010). Basically, we estimate tax-period effects for each city in our sample with the same method and settings (specifications and variable and observation order; see Section 3 and below) as for Basel. Since only Basel actually introduced the tax, the estimated effects in the other cities show the range of estimates that arise by chance. One can only consider the estimate for Basel statistically significant if it is among the largest of these estimates.

A poor fit in the pre-tax period often goes along with large differences in the tax period. This can be seen in Figs. 5, 6, and 7 in Appendix A. They depict the pre-tax fits and the tax effects for other cities for which we can approximate pre-tax electricity consumption ${ }^{11}$ (Panel A) and cities with at most twice Basel's pre-tax root mean squared prediction error (Panel B). Therefore, we look at the ratio of the root mean squared prediction errors of the tax and pre-tax periods in Basel and the other cities (as in Abadie et al. 2010; see also Ferman and Pinto 2017 for a discussion of this procedure).

Basel's ratio is the tenth largest out of 34 in the case of specification (i), the 21st largest out of 34 in the case of specification (ii), and the twelfth largest out of 34 in

\footnotetext{
${ }^{10}$ The peak in observed electricity consumption in 2001 is due to a change in the fiscal year of Basel's utility (personal communication with a representative of Basel's office for the environment and energy from May 4, 2018).

${ }^{11}$ The approximation is infeasible for Mendrisio in the case of specification (i) and (ii) and Locarno in the case of specification (iii).
} 
Electricity consumption (in MWh per household)
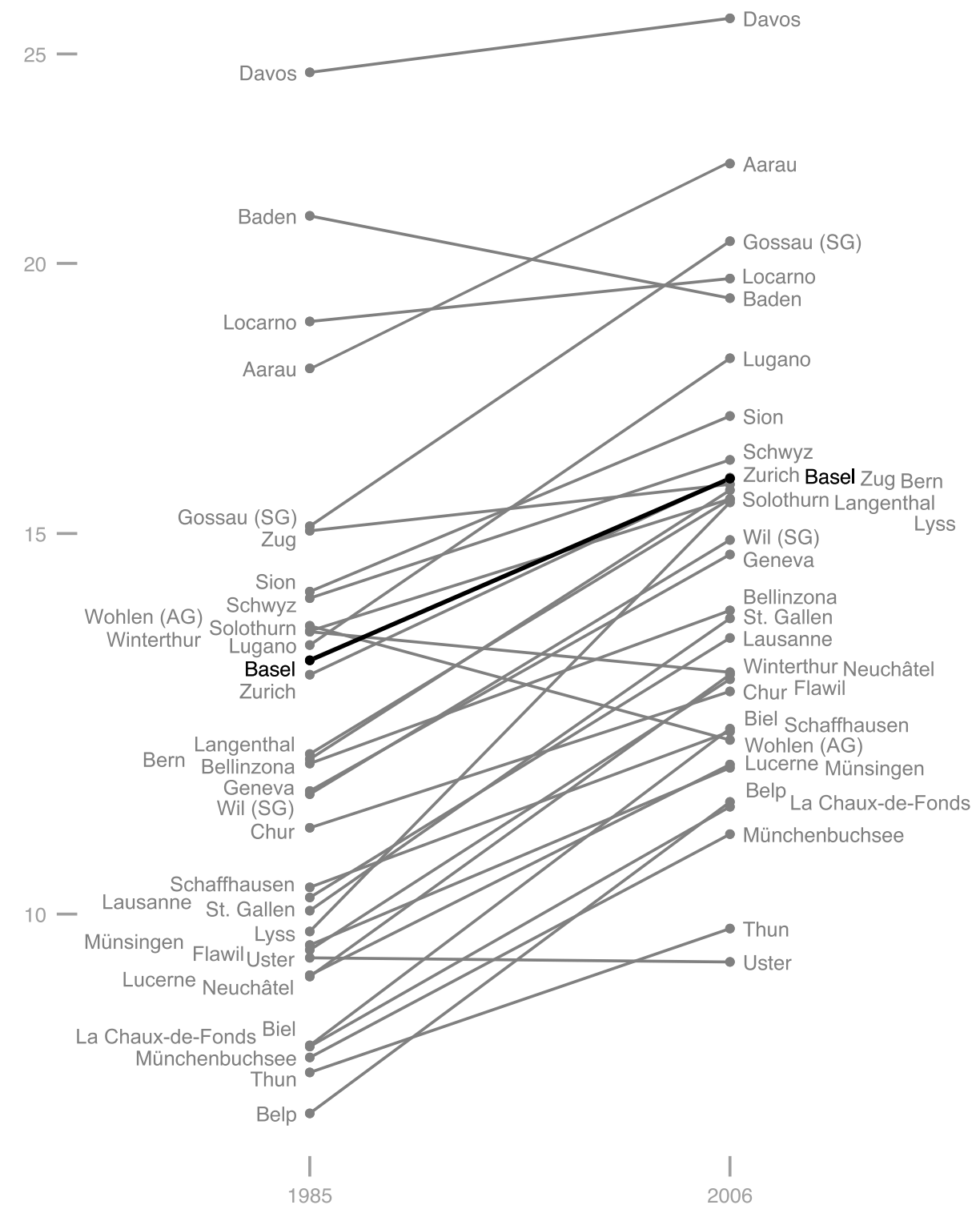

Fig. 2 Electricity consumption in 1985 and 2006 and its development in the Swiss cities. Notes: Logarithmic scale is used. The figures for Mendrisio are not shown as they are substantially larger (26.9 MWh per household in 1985 and $48.6 \mathrm{MWh}$ per household in 2006)

the case of specification (iii) (see Fig. 8). Under certain conditions (Ferman and Pinto 2017; Ferman et al. 2018), these figures would imply $p$-values of $0.294,0.618$, and 0.353 , respectively. This suggests that the estimates are insignificant. Because the distribution of estimates arising by chance may not be well approximated given the relatively small number of cities, these $p$-values need to be interpreted cautiously.

As discussed in Section 3, we estimate 1000 permutations of ordering cities and variables for each specification. The results presented so far are the ones for the corresponding permutations with the lowest root mean squared prediction error in the pre-tax years. In the case of specification (i), in which we only change the order of the cities, the root mean squared prediction error is identical (up to the eighth decimal place) for all 1000 permutations. Nevertheless, estimated average reductions slightly differ across permutations, 996 estimates amount to -0.433 , and four estimates to -0.422 . In the cases of specifications (ii) and (iii), the estimates differ more widely. Figure 9 in Appendix A shows that the estimates based on the lowest root mean squared prediction error are in the upper range of the estimates from all 1000 permutations. Figure 9 in Appendix A also depicts the 
Table 1 Variable values and weights with the three main specifications

\begin{tabular}{|c|c|c|c|c|c|c|c|c|}
\hline & \multirow{3}{*}{$\begin{array}{l}\text { Observed } \\
\text { Basel }\end{array}$} & \multirow{3}{*}{$\begin{array}{l}\text { Unweighted } \\
\text { average }\end{array}$} & \multicolumn{6}{|c|}{ Hypothetical } \\
\hline & & & \multicolumn{2}{|l|}{ (i) } & \multicolumn{2}{|l|}{ (ii) } & \multicolumn{2}{|l|}{ (iii) } \\
\hline & & & Values & Weights & Values & Weights & Values & Weights \\
\hline \multicolumn{9}{|l|}{ Variables } \\
\hline Consumption 1985 & 13.104 & 12.758 & 13.074 & 0.063 & 12.999 & - & 13.051 & - \\
\hline Consumption 1986 & 13.318 & 13.093 & 13.399 & 0.065 & 13.394 & - & 13.435 & - \\
\hline Consumption 1987 & 13.701 & 13.297 & 13.698 & 0.099 & 13.511 & - & 13.508 & - \\
\hline Consumption 1988 & 13.849 & 13.526 & 13.824 & 0.078 & 13.884 & - & 13.897 & - \\
\hline Consumption 1989 & 13.999 & 13.753 & 14.055 & 0.089 & 14.088 & - & 14.084 & - \\
\hline Consumption 1990 & 14.380 & 13.977 & 14.298 & 0.059 & 14.252 & - & 14.240 & - \\
\hline Consumption 1991 & 14.224 & 14.281 & 14.307 & 0.062 & 14.511 & - & 14.532 & - \\
\hline Consumption 1992 & 14.516 & 14.308 & 14.646 & 0.052 & 14.636 & - & 14.650 & - \\
\hline Consumption 1993 & 14.708 & 14.197 & 14.623 & 0.058 & 14.473 & - & 14.479 & - \\
\hline Consumption 1994 & 14.674 & 14.211 & 14.655 & 0.068 & 14.640 & - & 14.613 & - \\
\hline Consumption 1995 & 14.607 & 14.287 & 14.648 & 0.118 & 14.550 & - & 14.560 & - \\
\hline Consumption 1996 & 14.600 & 14.361 & 14.655 & 0.057 & 14.511 & - & 14.568 & - \\
\hline Consumption 1997 & 14.901 & 14.281 & 14.683 & 0.067 & 14.748 & - & 14.798 & - \\
\hline Consumption 1998 & 14.746 & 14.517 & 14.893 & 0.066 & 14.930 & - & 14.956 & - \\
\hline Avg. consumption & 14.238 & 13.918 & 14.247 & - & 14.223 & 0.646 & 14.241 & - \\
\hline Avg. electricity intensity & 0.047 & 0.048 & 0.048 & - & 0.047 & 0.347 & 0.047 & 0.324 \\
\hline Electric heating & 0.011 & 0.068 & 0.062 & - & 0.021 & 0.007 & 0.020 & 0.499 \\
\hline Electric boiler & 0.180 & 0.283 & 0.317 & - & 0.235 & 0.000 & 0.230 & 0.001 \\
\hline Rooms per apartment & 3.079 & 3.611 & 3.730 & - & 3.357 & 0.000 & 3.289 & 0.000 \\
\hline Avg. income & 69018 & 61027 & 62746 & - & 61799 & 0.000 & 62054 & 0.016 \\
\hline Working-age population & 0.673 & 0.668 & 0.668 & - & 0.679 & 0.000 & 0.684 & 0.015 \\
\hline Avg. age & 43.112 & 39.074 & 39.136 & - & 41.108 & 0.000 & 41.629 & 0.061 \\
\hline Heating-degree days & 3039.771 & 3505.875 & 3515.670 & - & 3384.192 & 0.000 & 3361.517 & 0.004 \\
\hline Cooling-degree days & 158.812 & 113.361 & 99.355 & - & 115.774 & 0.000 & 118.230 & 0.080 \\
\hline
\end{tabular}

Notes: The table shows the pre-tax levels of electricity consumption, its average, and its determinants for Basel, for an unweighted average of the other cities, and for three specifications (i), (ii), and (iii). The columns with the header "values" report weighted averages of these variables across cities. The columns with the header "weights" report the variable weights. The specifications differ with respect to the variables to be approximated. These are all pre-tax electricity consumption levels in specification (i), the average pre-tax electricity consumption and the determinants of electricity consumption in specification (ii), and only the determinants in specification (iii)

estimates based on the alternative selection criterion discussed in footnote 6, i.e., the lowest difference of pre-tax variables.

\section{Discussion}

To put our estimates into perspective, we calculate the implied elasticities by dividing the average consumption reductions of $-2.7,-2.2$, and $-1.9 \%$ from Section 4 by the overall price increase of 5.4 or $8.0 \%$ from Section $2^{12}$. The resulting elasticities are in the range of -0.5 to -0.2 .

These elasticities fall within the range of relevant previously reported estimates, but at the smaller end. First, of the three papers cited in Section 1 on the effects of electricity taxes in the manufacturing sector, only Bjørner

\footnotetext{
${ }^{12}$ As discussed in Section 2 our estimates essentially capture the pure substitution effect.
}

and Jensen (2002) for Denmark find an elasticity of similar magnitude $(-0.44)$. The elasticities reported in Martin et al. (2014) for the UK (-1.51) and in Gerster (2015) for Germany $(-1.58$ and -2.32$)$ are considerably bigger. Second, our implied elasticities are at the smaller end of the price elasticities for residential electricity demand in Swiss cities of -0.35 in 1987-1990 (Filippini 1999), -2.26 to -1.27 in 2000-2006 (Filippini 2011), and -0.58 in 2006-2012 (Boogen et al. 2017). They are close to, but smaller than the average value of the long-term elasticity of -0.51 in the meta analysis of Labandeira et al. (2017). Judging from this meta analysis, there is no reason to expect our estimates for overall electricity demand to substantially differ from the ones for industrial or residential electricity demand. However, several papers report considerably larger energy demand reactions to tax-induced 
Panel A
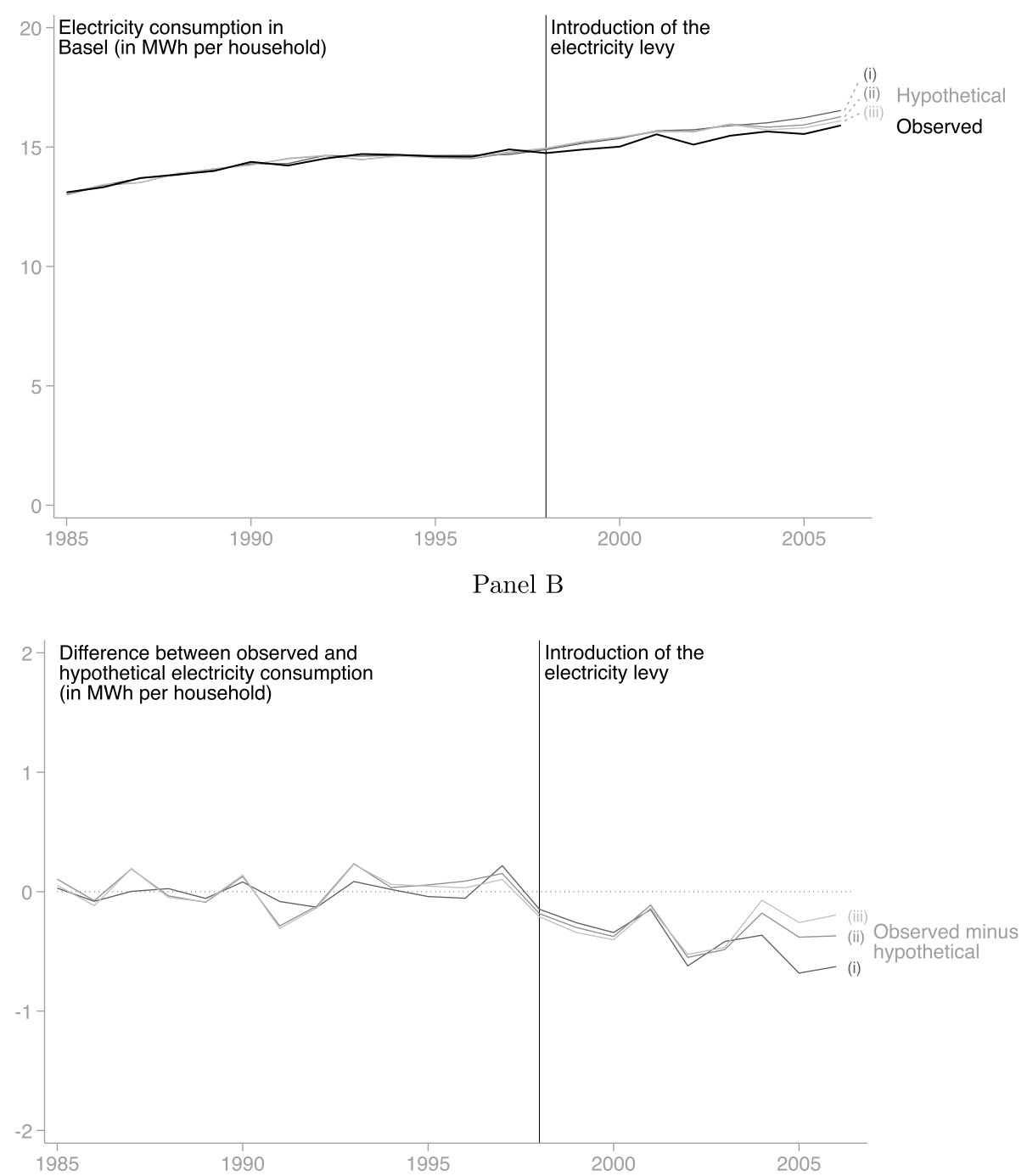

Fig. 3 Main results. Notes: Panel A shows the observed and the hypothetical electricity consumption in Basel, Panel B shows the difference between the observed and the hypothetical electricity consumption. (i), (ii), and (iii) refer to three different specifications. The variables to be approximated are all pre-tax electricity consumption levels in specification (i), the average pre-tax electricity consumption and the determinants of electricity consumption in specification (ii), and the determinants only in specification (iii)

price changes compared to other price fluctuations (Davis and Kilian 2011; Li et al. 2014; Antweiler and Gulati 2016; Andersson 2019; for a review, see Baranzini and Carattini 2014). Overall, therefore, the magnitude of our implied elasticities is probably below what one would expect based on the existing literature. Further, it is important to reiterate that our results are statistically insignificant.

What may explain the rather small effects? We see two related reasons. First, as discussed in Section 2, the introduction of the tax together with the other modifications clearly increased the marginal price of electricity. However, the change in the average price depended on consumption levels and was necessarily smaller, for a given consumption level, than the change in the marginal price. Our results may thus mirror Ito's (2014) finding that people react to average rather than to marginal electricity prices.

Second, this may have been reinforced by the official communication, which focused on the total costs of electricity for consumers. After the first presentation of the planned reforms (see Section 2), Basel's main newspaper quoted the relevant parliamentary commission stating that the consumers' electricity bills will not change ${ }^{13}$. This narrative endured even though media reports also men-

\footnotetext{
${ }^{13}$ Basler Zeitung, "Mit Lenkungsabgabe das Stromsparen fördern," July 23, 1998.
} 
tioned that the reform created conservation incentives ${ }^{14}$. The proximate reason for this unfortunate communication may lie in its focus on the introduction of the electricity tax and the permanent rebates. The large price changes only emerge if we consider all three reform elements including the replacement of the fixed monthly fee by higher marginal prices. Very few newspaper articles refer to this replacement ${ }^{15}$, and none reports the reform's overall effect on marginal prices. We do not speculate about ultimate reasons for this unfortunate communication. However, since purely informational measures can have effects on electricity consumption (Buckley 2020), it may well have affected the reforms' effectiveness.

\section{Conclusion}

The electricity tax introduced in Basel in 1999 substantially increased marginal prices by $5.4-8.0 \%$. However, based on our analysis with the synthetic control method, we find that aggregate electricity usage in the tax period was not noticeably lower than what it would have been without the tax. We find only a relatively small and statistically insignificant decrease of -2.7 to $-1.9 \%$.

Despite our findings, we are convinced that electricity taxes can be effective. In Section 5, we hypothesize that the small reaction of consumers might be due to ambiguous effects on average prices and the unfortunate official communication. Therefore, it seems important that future tax reforms have clear effects on both marginal and average prices and that they are easily communicable.

Context-specific factors such as the ones in Basel will always be present. Therefore, we deem it worthwhile to analyze comparable reforms in a range of other jurisdictions to assess the effectiveness of electricity taxes more generally and to identify critical factors thereof. Further, future research may also benefit from studying tax reforms with individual consumer data to investigate effect heterogeneity and the role of various prices.

\footnotetext{
${ }^{14}$ For examples of similar statements regarding electricity bills or prices, see: Neue Zürcher Zeitung, "Basler Modell einer Energielenkungsabgabe," July 23, 1998; Tages Anzeiger, "Basel geht in der Energiepolitik voran," July 23, 1998; Neue Mittelland Zeitung, "Eine bittere und eine süsse Pille für Basler Stromkonsumenten," July 24, 1998; Basler Zeitung, "Ein energiepolitischer Kraftakt im Grossen Rat," September 10, 1998; Basler Zeitung,

“'Kaiseraugst-Dividende’ für Basler Bevölkerung," May 18, 1999; Neue Zürcher Zeitung, "Basler Strom-Lenkungsabgabe in Kraft," May 18, 1999; Basler Zeitung, "Strombonus erfüllt Erwartungen," June 27, 2000; Basler Zeitung, "Energieabgaben - Gute Basler Erfahrungen," August 19, 2000; Neue Zürcher Zeitung, "Basel als Pionier in Sachen Energieabgaben," September 19, 2000; Basler Zeitung, "Basler Lenkungsabgabe senkt Umweltbelastung," November 4, 2002; Basler Zeitung, "BS-Energiegesetz wirkt," June 24, 2003. We identified (mostly through Factiva) 96 articles in Swiss newspapers in the years

1994-2003 that mention the reform or the electricity tax. Of these, around $59 \%$ do not discuss price changes or conservation incentives, around $13 \%$ contain detailed information about price changes, and around $29 \%$ mention conservation incentives. Around $26 \%$ point to the permanent rebates.

${ }^{15}$ Examples are Neue Zürcher Zeitung, "Basler Modell einer Energielenkungsabgabe," July 23, 1998; Basler Zeitung, "Neue Ratsmitglieder," September 10, 1998 .
} 


\section{Appendix A. Tables and figures}

Table 2 The change of electricity prices

\begin{tabular}{|c|c|c|c|c|c|c|c|c|}
\hline \multirow[t]{2}{*}{ Tariff } & $\begin{array}{l}\text { Fixed } \\
\text { monthly } \\
\text { fee }^{a}\end{array}$ & $\begin{array}{l}\text { Marginal } \\
\text { price }^{a, b}\end{array}$ & $\begin{array}{l}\text { Marginal } \\
\text { price incl. } \\
\text { rebate }^{c}\end{array}$ & $\begin{array}{l}\text { Electricity } \\
\operatorname{tax}^{d}\end{array}$ & $\begin{array}{l}\text { Further } \\
\operatorname{tax}^{c}\end{array}$ & $\begin{array}{l}\text { Total } \\
\text { marginal } \\
\text { price }\end{array}$ & \multirow{2}{*}{$\begin{array}{l}\text { Change } \\
\text { Percent }\end{array}$} & \multirow{2}{*}{$\begin{array}{l}\text { Conumption } \\
\text { in } 1998^{e} \\
\text { GWh }\end{array}$} \\
\hline & \multicolumn{6}{|c|}{$\mathrm{CHF} /$ month $\mathrm{CHF} / \mathrm{kWh}$} & & \\
\hline \multicolumn{9}{|l|}{ Before } \\
\hline Households single tariff & 4 & 0.213 & 0.202 & - & 0.009 & 0.211 & - & 205.1 \\
\hline Households double tariff, high & 8 & 0.213 & 0.202 & - & 0.009 & 0.211 & - & 27.4 \\
\hline Households double tariff, low & 8 & 0.074 & 0.070 & - & 0.003 & 0.073 & - & 41.0 \\
\hline Small businesses single tariff & 4 & 0.213 & 0.202 & - & 0.009 & 0.211 & - & 114.2 \\
\hline Small businesses double tariff, high & 8 & 0.213 & 0.202 & - & 0.009 & 0.211 & - & 24.5 \\
\hline Small businesses double tariff, low & 8 & 0.074 & 0.070 & - & 0.003 & 0.073 & - & 25.6 \\
\hline Mid-sized businesses, summer, high & $n / a^{*}$ & 0.166 & 0.158 & - & 0.007 & 0.164 & - & 62.1 \\
\hline Mid-sized businesses, winter, high & $n / a^{*}$ & 0.212 & 0.201 & - & 0.009 & 0.210 & - & 84.0 \\
\hline Mid-sized businesses, summer, low & $n / a^{*}$ & 0.070 & 0.665 & - & 0.003 & 0.069 & - & 36.5 \\
\hline Mid-sized businesses, winter, low & $n / a^{*}$ & 0.104 & 0.988 & - & 0.004 & 0.103 & - & 49.3 \\
\hline \multicolumn{9}{|l|}{ After } \\
\hline Households single tariff & - & 0.195 & - & 0.037 & 0.009 & 0.241 & 14.4 & 205.1 \\
\hline Households double tariff, high & - & 0.220 & - & 0.056 & 0.011 & 0.287 & 36.1 & 27.4 \\
\hline Households double tariff, low & - & 0.070 & - & 0.026 & 0.004 & 0.100 & 36.3 & 41.0 \\
\hline Small businesses single tariff & - & 0.157 & - & 0.059 & 0.009 & 0.225 & 6.5 & 114.2 \\
\hline Small businesses double tariff, high & - & 0.177 & - & 0.060 & 0.010 & 0.247 & 16.9 & 24.5 \\
\hline Small businesses double tariff, low & - & 0.057 & - & 0.043 & 0.004 & 0.104 & 42.0 & 25.6 \\
\hline Mid-sized businesses, summer, high & $n / a^{*}$ & 0.120 & - & 0.060 & 0.007 & 0.187 & 13.9 & 62.1 \\
\hline Mid-sized businesses, winter, high & $n / a^{*}$ & 0.154 & - & 0.060 & 0.009 & 0.223 & 6.0 & 84.0 \\
\hline Mid-sized businesses, summer, low & $n / a^{*}$ & 0.051 & - & 0.043 & 0.004 & 0.098 & 41.1 & 36.5 \\
\hline Mid-sized businesses, winter, low & $n / a^{*}$ & 0.075 & - & 0.043 & 0.005 & 0.123 & 19.2 & 49.3 \\
\hline
\end{tabular}

Notes: All prices are excluding VAT. The rebate in the third column refers to the temporary rebate granted retroactively to avoid excessive profits

*Depends on high-voltage usage. Did not change.

Sources: a Decree on electricity tariffs ("Verordnung betreffend Elektrizitätstarife") from November 29, 1994; b Decree on electricity tariffs ("Verordnung betreffend Elektrizitätstarife") from May 11, 1999; ' ${ }^{\prime \prime}$ ten et al. (2003, pp. 7-8); ' Decree on the electricity tax ("Verordnung zur Lenkungsabgabe und zum Strompreis-Bonus") from May 11, 1999; ${ }^{e}$ Iten et al. (2003, p. 208) 
Table 3 City weights with the three main specifications

\begin{tabular}{|c|c|c|c|}
\hline & (i) & (ii) & (iii) \\
\hline \multicolumn{4}{|l|}{ Cities } \\
\hline Aarau & 0.296 & 0 & 0 \\
\hline Baden & 0 & 0.122 & 0.127 \\
\hline Bellinzona & 0 & 0 & 0 \\
\hline Belp & 0.040 & 0 & 0 \\
\hline Bern & 0 & 0 & 0 \\
\hline Biel & 0 & 0 & 0 \\
\hline Chur & 0 & 0 & 0 \\
\hline Davos & 0 & 0 & 0 \\
\hline Flawil & 0.143 & 0.079 & 0 \\
\hline Geneva & 0 & 0 & 0 \\
\hline Gossau & 0 & 0 & 0 \\
\hline La Chaux-de-Fonds & 0 & 0 & 0 \\
\hline Langenthal & 0 & 0 & 0 \\
\hline Lausanne & 0 & 0 & 0 \\
\hline Locarno & 0 & 0 & 0 \\
\hline Lucerne & 0.157 & 0.379 & 0.449 \\
\hline Lugano & 0 & 0 & 0 \\
\hline Lyss & 0 & 0 & 0 \\
\hline Mendrisio & 0.022 & 0.057 & 0.050 \\
\hline Münchenbuchsee & 0 & 0 & 0 \\
\hline Münsingen & 0 & 0 & 0 \\
\hline Neuchâtel & 0 & 0.024 & 0 \\
\hline Schaffhausen & 0 & 0 & 0 \\
\hline Schwyz & 0 & 0 & 0 \\
\hline Sion & 0 & 0 & 0 \\
\hline Solothurn & 0 & 0 & 0 \\
\hline St. Gallen & 0 & 0 & 0 \\
\hline Thun & 0 & 0 & 0 \\
\hline Uster & 0.070 & 0 & 0 \\
\hline Wil & 0.128 & 0 & 0 \\
\hline Winterthur & 0 & 0 & 0 \\
\hline Wohlen & 0.034 & 0 & 0 \\
\hline Zug & 0 & 0 & 0 \\
\hline Zurich & 0.111 & 0.338 & 0.374 \\
\hline
\end{tabular}

Notes: (i), (ii), and (iii) refer to the three different specifications. The variables to be approximated are all pre-tax electricity consumption levels in specification (i), the average pre-tax electricity consumption and the determinants of electricity consumption in specification (ii), and only the determinants in specification (iii) 


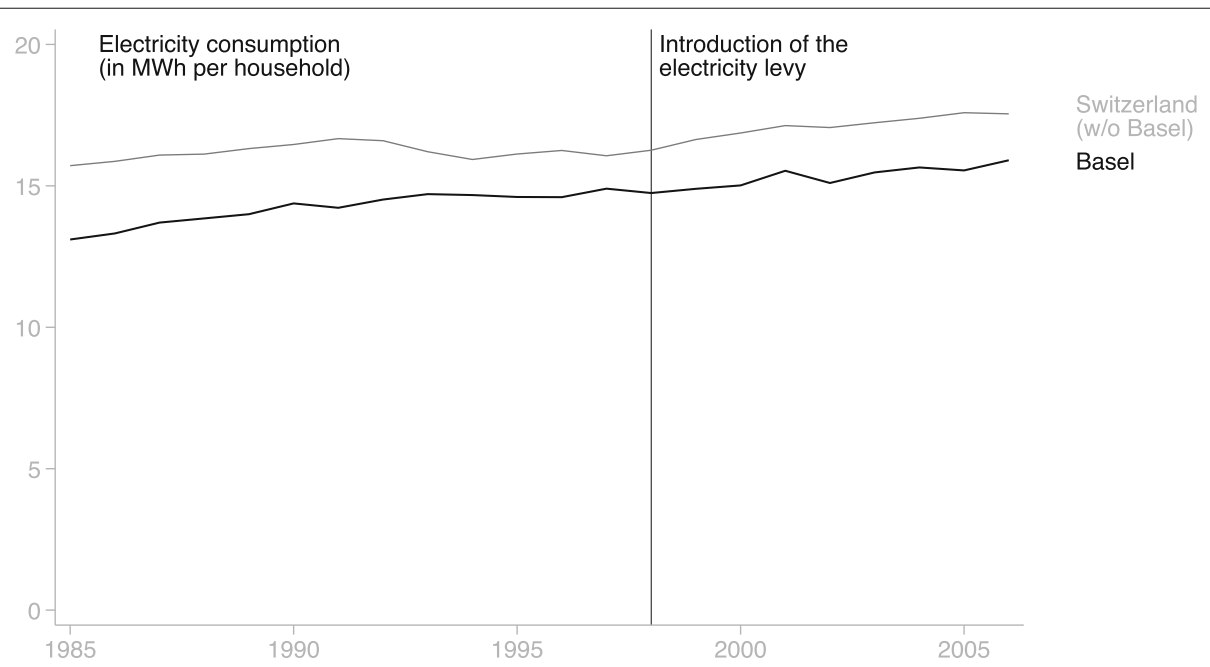

Fig. 4 Comparison Basel vs. Switzerland. Notes: The figure depicts the electricity consumption per household in Basel (black line) and the rest of Switzerland (gray line). Sources: For Basel, see Appendix B. For Switzerland, the data are from SFOE (2018) 


\section{Panel A}

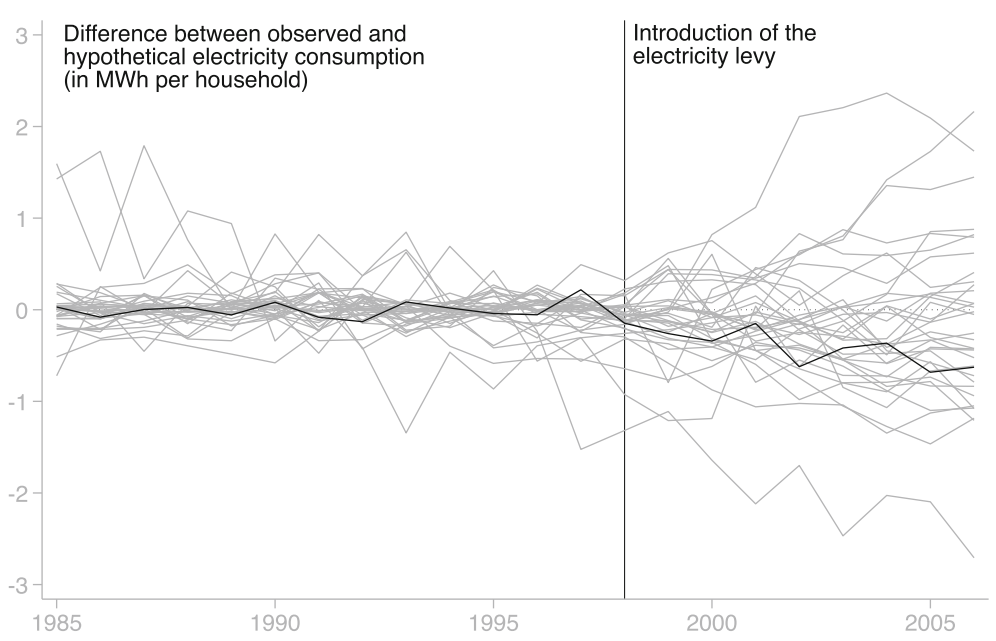

Observed minus hypothetical

Panel B

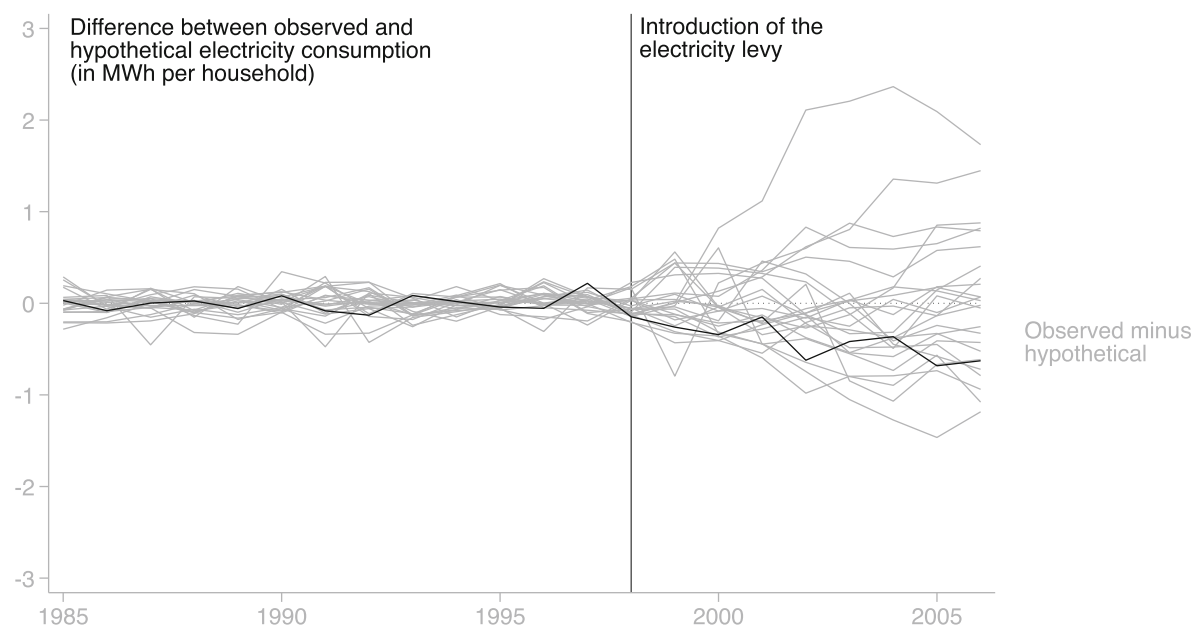

Fig. 5 Placebo estimates for specification (i). Notes: The figure shows the pre-tax fits and the post-tax effects for Basel and other cities which did not actually introduce an electricity tax. Panel A includes 33 other cities for which we can approximate pre-tax electricity consumption. The approximation is infeasible for Mendrisio. Panel B includes 24 cities with at most twice Basel's pre-tax root mean squared prediction error 


\section{Panel A}
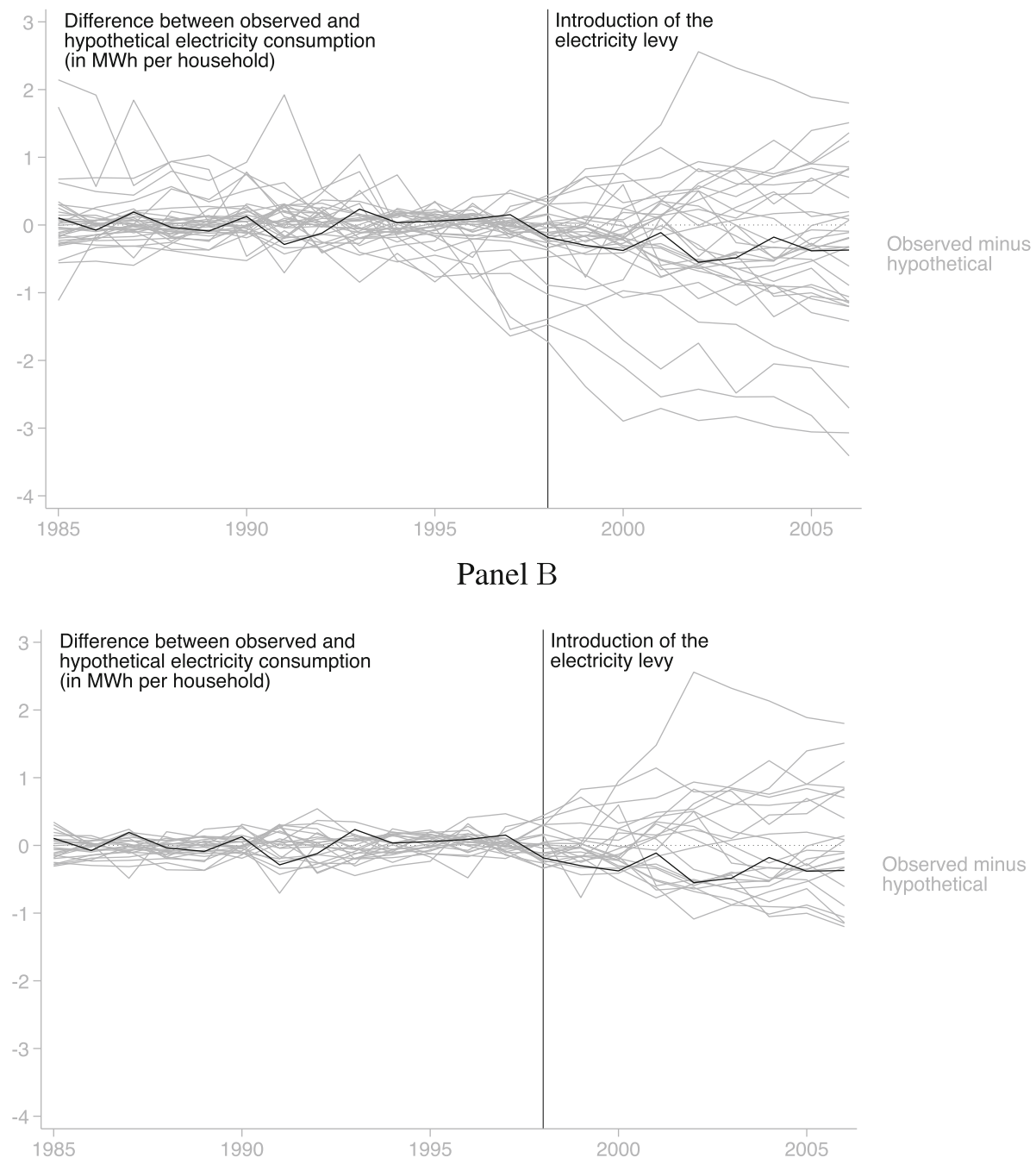

Fig. 6 Placebo estimates for specification (ii). Notes: The figure shows the pre-tax fits and the post-tax effects for Basel and other cities which did not actually introduce an electricity tax. Panel A includes 33 other cities for which we can approximate pre-tax electricity consumption. The approximation is infeasible for Mendrisio. Panel B includes 23 cities with at most twice Basel's pre-tax root mean squared prediction error 


\section{Panel A}

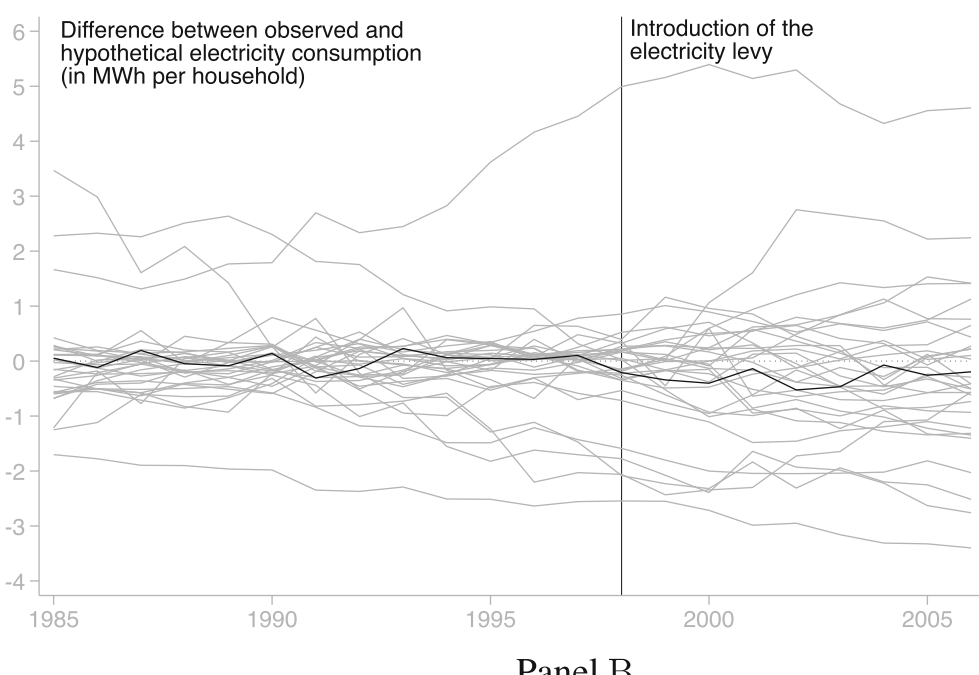

Observed minus hypothetical

Panel B

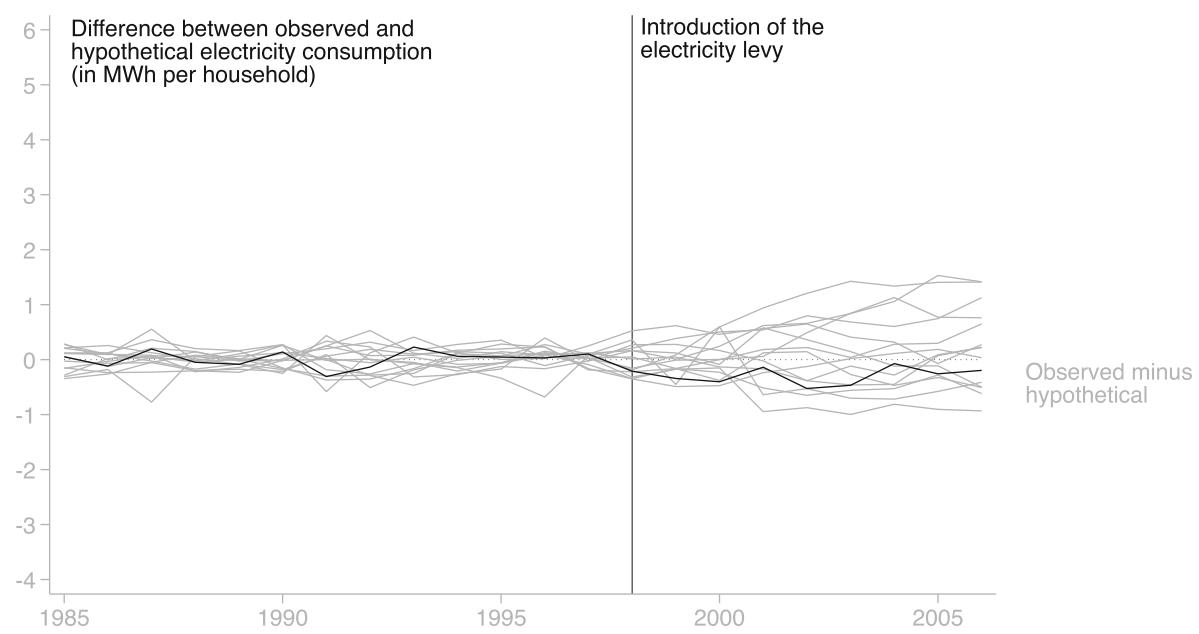

Fig. 7 Placebo estimates for specification (iii). Notes: The figure shows the pre-tax fits and the post-tax effects for Basel and other cities which did not actually introduce an electricity tax. Panel A includes 31 other cities for which we can approximate pre-tax electricity consumption. The approximation is infeasible for Locarno. Further, Davos and Mendrisio are left out of the figure because they are too far out. Panel B includes 14 cities with at most twice Basel's pre-tax root mean squared prediction error 


\section{Sepcification (i)}

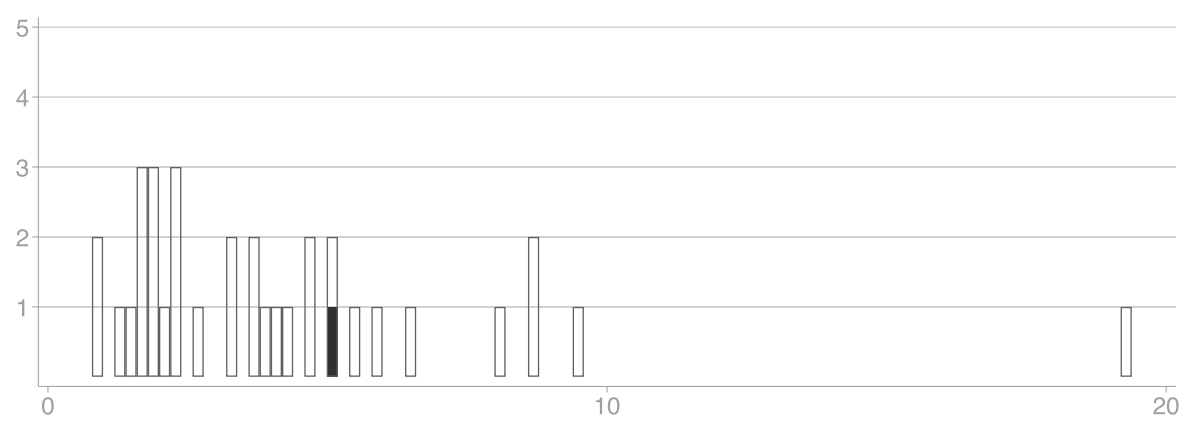

Sepcification (ii)

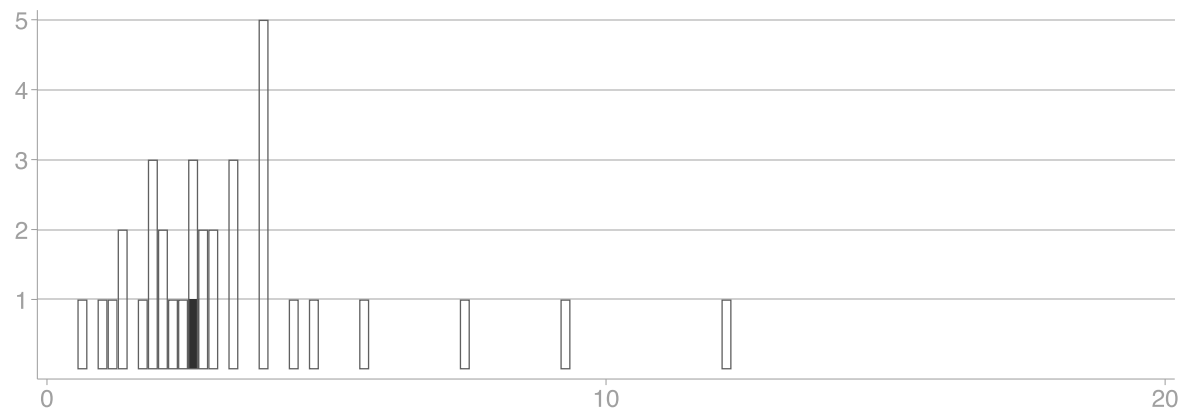

Sepcification (iii)

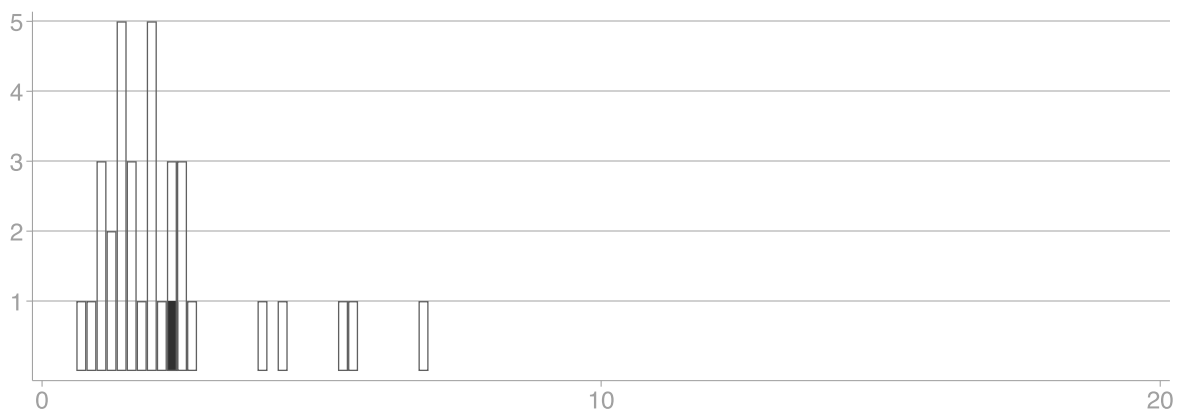

Fig. 8 Relative root mean squared prediction error. Notes: This figure shows the relative root mean squared prediction errors for Basel (black bars) and all other cities (white bars). (i), (ii), and (iii) refer to the three different specifications. The variables to be approximated are all pre-tax electricity consumption levels in specification (i), the average pre-tax electricity consumption and the determinants of electricity consumption in specification (ii), and only the determinants in specification (iii) 


\section{Panel A}
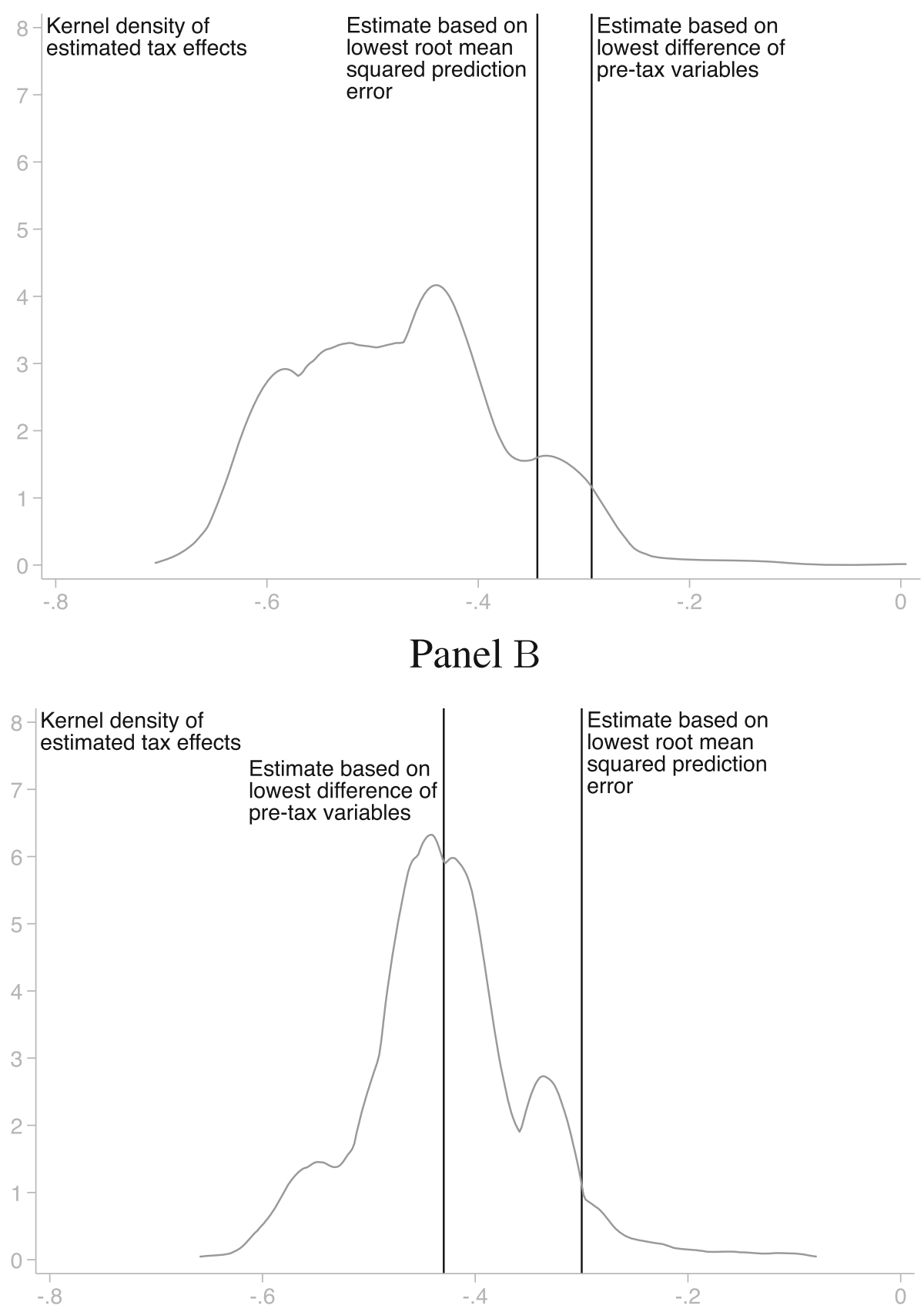

Fig. 9 Robustness. Notes: The figure depicts Kernel density estimates of the distribution of the estimated average reduction of electricity consumption for 1000 permutations for specification (ii) in Panel A and specification (iii) in Panel B. The variables to be approximated are the average pre-tax electricity consumption and the determinants of electricity consumption in specification (ii) and only the determinants in specification (iii). The figure also shows the estimates based on the lowest root mean squared prediction error and the lowest difference of the pre-tax variables (see Section 3 and footnote 6 for details) 


\section{Appendix B. Data}

\section{Electricity consumption}

Aarau Source: IBAarau Strom AG

Additionally included municipalities: Attelwil, Biberstein, Bottenwil, Buchs (AG), Densbüren, Eppenberg-Wöschnau, Erlinsbach (AG), Erlinsbach (SO), Hirschthal, Holziken, Kirchleerau, Küttigen, Moosleerau, Reitnau, Rohr (SO), Staffelbach, Unterentfelden, Wiliberg

Notes: For the years 1992-1999, only gross consumption values are available. We use these values and the second method of Section 3 to fill in the missing net values.

Baden Source: Regionalwerke AG Baden Additionally included municipality: Ennetbaden

Basel Source: Industrielle Werke Basel Additionally included municipalities: Bettingen, Riehen

Bellinzona Source: Azienda Elettrica Ticinese Additionally included municipalities: ArbedoCastione, Cadenazzo, Camorino, Giubiasco, Gnosca, Gorduno, Lumino, Monte Carasso, Pianezzo, Sant'Antonino, Sant'Antonio, Sementina

Belp Source: Energie Belp AG

Bern Source: Energie Wasser Bern

Biel/Bienne Source: Energie Service Biel/Bienne

Chur Source: IBC Energie Wasser Chur Notes: We fill in the missing values for the years 2002-2006 with the first method of Section 3.

Davos Source: EWD Elektrizitätswerk Davos AG

Flawil Source: Technische Betriebe Flawil

Geneva Source: Services Industriels de Genève Additionally included municipalities: Aire-la-Ville, Anières, Avully, Avusy, Bardonnex, Bellevue, Bernex, Carouge (GE), Cartigny, Chancy, Choulex, ChêneBougeries, Chêne-Bourg, Collex-Bossy, CollongeBellerive, Cologny, Confignon, Corsier (GE), Dardagny, Genthod, Gy, Hermance, Jussy, Laconnex, Lancy, Le Grand-Saconnex, Meinier, Meyrin, Onex, Perly-Certoux, Plan-les-Ouates, Pregny-Chambésy, Presinge, Puplinge, Russin, Satigny, Soral, Thônex, Troinex, Vandoeuvres, Vernier, Versoix, Veyrier

Gossau (SG) Source: Stadtwerke Gossau

Langenthal Source: IB Langenthal AG

Lausanne Source: Services Industriels de Lausanne Notes: For the years 1985-1986 only total sales (including sales to other utilities) are available. We use these figures and the second method of Section 3 to fill in the missing net values.

La Chaux-de-Fonds Source: Services Industriels La Chaux-de-Fonds

Notes: We fill in the missing value for the year 2003 with the third method of Section 3.
Locarno Source: Azienda Elettrica Ticinese Additionally included municipalities: Avegno Gordevio, Biasca, Blenio, Bodio, Bosco/Gurin, Brione (Verzasca), Brione sopra Minusio, Brissago, Campo (Vallemaggia), Castaneda, Cavigliano, Centovalli, Cerentino, Cevio, Claro, Corippo, Cresciano, Cugnasco-Gerra, Dalpe, Frasco, Giornico, Gordola, Gresso, Grono, Gudo, Iragna, Isorno, Lavertezzo, Lavizzara, Linescio, Lodrino, Losone, Maggia, Mergoscia, Minusio, Moleno, Mosogno, Muralto, Onsernone, Orselina, Osogna, Personico, Pollegio, Prato (Leventina), Preonzo, Quinto, Ronco sopra Ascona, Roveredo (GR), Santa Maria in Calanca, Serravalle, Sobrio, Sonogno, Tegna, Tenero-Contra, Vergeletto, Verscio, Vogorno

Lucerne Source: LUSTAT Statistik Luzern

Notes: Starting 2004 the electricity usage and household data include Littau, which merged to Lucerne.

Lugano Source: Azienda Elettrica Ticinese

Additionally included municipalities: Agno, Alto Malcantone, Aranno, Arogno, Astano, Bedano, Bedigliora, Besazio, Bioggio, Bissone, Bogno, Breggia, Brusino Arsizio, Cademario, Cadempino, Cadro, Canobbio, Carona, Caslano, Castel San Pietro, Certara, Cimadera, Coldrerio, Collina d'Oro, Comano, Croglio, Cureglia, Curio, Grancia, Gravesano, Lamone, Magliaso, Manno, Maroggia, Melano, Melide, Meride, Mezzovico-Vira, Miglieglia, Monteceneri, Monteggio, Morcote, Muzzano, Neggio, Novaggio, Novazzano, Origlio, Paradiso, Ponte Capriasca, Porza, Pura, Riva San, Vitale, Rovio, Savosa, Sessa, Sorengo, Torricella-Taverne, Valcolla, Vernate, Vezia, Vico, Morcote

Lyss Source: Energie Seeland AG Additionally included municipality: Grossaffoltern

Mendrisio Source: Azienda Elettrica Ticinese Additionally included municipality: Ligornetto

Münchenbuchsee Source: Energie Münchenbuchsee AG

Münsingen Source: InfraWerke Münsingen

Neuchâtel Source: Services Industriels de la Ville de Neuchâtel

Notes: We fill in the missing value for the year 1985 with the first method of Section 3.

St. Gallen Source: St. Galler Stadtwerke

Notes: There are two outliers in the data in 1994 and 2004 due to a switch in the metering period from calender year to hydrological year and back. We replace these outliers with the third method.

Schaffhausen Sources: Städtische Werke Schaffhausen and Elektrizitätswerk des Kantons Schaffhausen AG Notes: We fill in the missing values for the years 1985-1990 with the first method of Section 3. 
Schwyz Source: Elektrizitätswerk des Bezirks Schwyz AG

Additionally included municipalities: Illgau, Lauerz, Muotathal, Sattel, Steinen, Unteriberg

Sion Source: L'Énergie de Sion-Région SA

Additionally included municipalities: Arbaz, Ayent, Chermignon, Conthey, Evolène, Grimisuat, Hérémence, Icogne, Lens, Les Agettes, Mont-Noble, Saint-Léonard, Saint-Martin (VS), Salins, Savièse, Vex, Veysonnaz, Vétroz

Solothurn Source: Städtische Werke Solothurn

Thun Source: Energie Thun AG

Uster Source: Energie Uster

Wil (SG) Source: Technische Betriebe Wil

Winterthur Source: Stadtwerk Winterthur

Wohlen (AG) Source: IB Wohlen AG

Zug Source: WWZ Energie AG

Notes: The years 1986 and 2006 are missing. We use the third method to fill in the missing value for 1986 and the first method to fill in the missing value for 2006.

Zurich Source: Elektrizitätswerk der Stadt Zürich

\section{Households and determinants}

Household numbers

Sources: Private households by household size and region, 1980, 1990, 2000, and 2012, Federal population census, Federal Statistical Office

Average electricity intensity

Sources: Arbeitsstätten und Beschäftigte nach Kanton, Wirtschaftsabteilung und Grössenklasse, Statistik der Unternehmensstruktur, 2001, Federal Statistical Office; Energieeinsatzkonto der Haushalte und der Wirtschaft, 2000, Federal Statistical Office; Vollzeitäquivalente nach NOGA 2008, Abteilung und Gemeinden, Ebene Arbeitsstätte, Federal Statistical Office, Betriebszählung 1995, alle drei Sektoren, 1995, Federal Statistical Office

Electric heating

Source: Gebäude- und Wohnungserhebung der Volkszählung 1990, Federal Statistical Office

\section{Electric boiler}

Source: Gebäude- und Wohnungserhebung der Volkszählung 1990, Federal Statistical Office

Rooms per apartment

Source: Gebäude- und Wohnungserhebung der Volkszählung 1990, Federal Statistical Office

Average income

Source: Statistik der direkten Bundessteuer DBSt, 1997/1998, Federal Tax Administration
Working-age population

Source: Wohnbevölkerung am wirtschaftlichem Wohnsitz nach institutionellen Gliederungen, Geschlecht und Alter, 1990, Federal Statistical Office

Average age

Source: Wohnbevölkerung am wirtschaftlichem Wohnsitz nach institutionellen Gliederungen, Geschlecht und Alter, 1990, Federal Statistical Office

Heating-degree days

Source: MeteoSchweiz

Cooling-degree days

Source: MeteoSchweiz

\section{Supplementary Information}

The online version contains supplementary material available at https://doi.org/10.1186/s41937-020-00064-8.

Additional file 1: Data and code.

\section{Acknowledgements}

We would like to thank Marcus Diacon and Patrick Meier for many clarifying discussions and comments as well as for the provision of data. For research assistance, we thank Eliane Debrunner, Valerie Koller, Simona Richard, Jonas Röllin, and Tatjana Rütimann. Further, we are grateful for all comments made by participants at the research seminars in Neuchâtel and Lucerne and at the conferences on Energy-efficient Households (Social Sciences and Practice in Dialogue) in Winterthur, Energy Law and Economics in Lucerne, and on Human Dimensions of Environmental Risks in Ascona. Finally, we would like to thank the editor Rafael Lalive, the co-editor Conny Wunsch, and two anonymous reviewers for excellent comments and suggestions.

Authors' contributions

Both authors contributed equally to the data analysis and the writing of the paper. The authors read and approved the final manuscript.

\section{Funding}

This research was supported by the Swiss National Science Foundation (NRP 71 "Managing Energy Consumption").

Availability of data and materials

Data and codes are available on the journal website.

\section{Competing interests}

The authors declare that they have no competing interests.

Received: 15 February 2020 Accepted: 24 September 2020

Published online: 01 December 2020

\section{References}

Abadie, A., Diamond, A., Hainmueller, J. (2010). Synthetic control methods for comparative case studies: estimating the effect of California's tobacco control program. Journal of the American Statistical Association, 105(490), 493-505.

Abadie, A., Diamond, A., Hainmueller, J. (2015). Comparative politics and the synthetic control method. American Journal of Political Science, 59(2), 495-510.

Abadie, A., \& Gardeazabal, J. (2003). The economic costs of conflict: a case study of the Basque Country. American Economic Review, 93(1), 113-132.

Alberini, A., \& Filippini, M. (2011). Response of residential electricity demand to price: the effect of measurement error. Energy Economics, 33(5), 889-895. 
Andersson, J.J. (2019). Carbon taxes and $\mathrm{CO}_{2}$ emissions: Sweden as a case study. American Economic Journal: Economic Policy, 11(4), 1-30.

Antweiler, W., \& Gulati, S. (2016). Frugal cars or frugal drivers? How carbon and fuel taxes influence the choice and use of cars. Unpublished manuscript.

Aroonruengsawat, A., Auffhammer, M., Sanstad, A.H. (2012). The impact of state level building codes on residential electricity consumption. Energy Journal, 33(1), 31-52.

Baranzini, A., \& Carattini, S. (2014). Taxation of emissions of greenhouse gases: the environmental impact of carbon taxes. In B. Freedman (Ed.), Global Environmental Change. Handbook of Global Environmental Pollution, Vol. 1 (pp. 543-560): Springer.

Bjørner, T.B., \& Jensen, H.H. (2002). Energy taxes, voluntary agreements and investment subsidies - a micro-panel analysis of the effect on Danish industrial companies' energy demand. Resource and Energy Economics, 24(3), 229-249.

Blázquez, L., Boogen, N., Filippini, M. (2013). Residential electricity demand in Spain: new empirical evidence using aggregate data. Energy Economics, 36, 648-657.

Boogen, N., Datta, S., Filippini, M. (2017). Dynamic models of residential electricity demand: evidence from Switzerland. Energy Strategy Reviews, 18, 85-92.

Botosaru, I., \& Ferman, B. (2019). On the role of covariates in the synthetic control method. Econometrics Journal, 22(2), 117-130.

Buckley, P. (2020). Prices, information and nudges for residential electricity conservation: a meta-analysis. Ecological Economics, 172.

Davis, L.W., \& Kilian, L. (2011). Estimating the effect of a gasoline tax on carbon emissions. Journal of Applied Econometrics, 26(7), 1187-1214.

Ferman, B., \& Pinto, C. (2017). Placebo tests for synthetic controls. Unpublished manuscript.

Ferman, B., Pinto, C., Possebom, V. (2018). Cherry picking with synthetic controls. Unpublished manuscript.

Filippini, M. (1999). Swiss residential demand for electricity. Applied Economics Letters, 6(8), 533-538.

Filippini, M. (2011). Short- and long-run time-of-use price elasticities in Swiss residential electricity demand. Energy Policy, 39(10), 5811-5817.

Gerster, A. (2015). Do electricity prices matter? Plant-level evidence from German manufacturing. Unpublished manuscript.

IEA (2018). Energy Prices and Taxes, Volume 2018 Issue 1: First Quarter 2018. Paris: OECD Publishing. https://doi.org/10.1787/energy taxv2018-1-en.

Iten, R., Vettori, A., Schmid, R. (2003). Evaluation des Stromsparfonds Basel: Swiss Federal Office of Energy.

Ito, K. (2014). Do consumers respond to marginal or average price? Evidence from nonlinear electricity pricing. American Economic Review, 104(2), 537-563.

Kaul, A., Klößner, S., Pfeifer, G., Schieler, M. (2018). Synthetic control methods: never use all pre-intervention outcomes together with covariates. Unpublished manuscript.

Klößner, S., Kaul, A., Pfeifer, G., Schieler, M. (2018). Comparative politics and the synthetic control method revisited: a note on Abadie et al. 2015. Swiss Journal of Economics and Statistics, 154(1), 1-11.

Labandeira, X., Labeaga, J.M., López-Otero, X. (2017). A meta-analysis on the price elasticity of energy demand. Energy Policy, 102, 549-568.

Li, S., Linn, J., Muehlegger, E. (2014). Gasoline taxes and consumer behavior. American Economic Journal: Economic Policy, 6(4), 302-342.

Maddala, G.S., Trost, R.P., Li, H., Joutz, F. (1997). Estimation of short-run and long-run elasticities of energy demand from panel data using shrinkage estimators. Journal of Business \& Economic Statistics, 15(1), 90-100.

Martin, R., De Preux, L.B., Wagner, U.J. (2014). The impact of a carbon tax on manufacturing: evidence from microdata. Journal of Public Economics, 117, $1-14$.

Romero-Jordán, D., Peñasco, C., del Río, P. (2014). Analysing the determinants of household electricity demand in Spain. An econometric study. International Journal of Electrical Power \& Energy Systems, 63, 950-961.

SFOE (1999). Swiss Federal Office of Energy - Schweizerische Elektrizitätsstatistik 1999.

SFOE (2015). Swiss Federal Office of Energy - Analyse des schweizerischen Energieverbrauchs 2000 - 2014 nach Verwendungszwecken.

SFOE (2016). Swiss Federal Office of Energy - Faktenblatt Stromverbrauch Elektrogeräte.

SFOE (2018). Swiss Federal Office of Energy - Schweizerische Elektrizitätsstatistik 2018.

SFSO (2008). Federal Statistical Office - Statistik der Schweizer Städte 2007.

\section{Publisher's Note}

Springer Nature remains neutral with regard to jurisdictional claims in published maps and institutional affiliations.

\section{Submit your manuscript to a SpringerOpen ${ }^{\circ}$ journal and benefit from:}

- Convenient online submission

Rigorous peer review

- Open access: articles freely available online

- High visibility within the field

- Retaining the copyright to your article

Submit your next manuscript at $>$ springeropen.com 